\title{
Quantum Mechanics/Molecular Mechanics Study on Caspase-2 Recognition by Peptide Inhibitors
}

\author{
Petar M. Mitrasinovic ${ }^{*}$ \\ Center for Biophysical and Chemical Research, Belgrade Institute of Science and Technology, 11060 Belgrade, Serbia \\ ${ }^{*}$ Corresponding author: E-mail: pmitrasinovic.ist-belgrade.edu.rs@tech-center.com
}

Received: 01-17-2020

\begin{abstract}
For a variety of biological and medical reasons, the ongoing development of humane caspase-2 inhibitors is of vital importance. Herein, a hybrid (Quantum Mechanics/Molecular Mechanics - QM/MM), two-layered molecular model is derived in order to understand better the affinity and specificity of peptide inhibitor interaction with caspase-2. By taking care of both the unique structural features and the catalytic activity of human caspase-2, the critical enzyme residues (E217, R378, N379, T380, and Y420) with the peptide inhibitor are treated at QM level (the Self-Consistent-Charge Density-Functional Tight-Binding method with the Dispersion correction (SCC-DFTB-D)), while the remaining part of the complex is treated at MM level (AMBER force field). The QM/MM binding free energies (BFEs) are well-correlated with the experimental observations and indicate that caspase-2 uniquely prefers a penta-peptide such as VDVAD. The sequence of VDVAD is varied in a systematic fashion by considering the physicochemical properties of every constitutive amino acid and its substituent, and the corresponding BFE with the inhibition constant $\left(K_{\mathrm{i}}\right)$ is evaluated. The values of $K_{\mathrm{i}}$ for several caspase-2:peptide complexes are found to be within the experimental range (between $0.01 \mathrm{nM}$ and 1 $\mu \mathrm{M})$. The affinity order is: VELAD $\left(K_{\mathrm{i}}=0.081 \mathrm{nM}\right)>\operatorname{VDVAD}\left(K_{\mathrm{i}}=0.23 \mathrm{nM}\right)>\operatorname{VEIAD}\left(K_{\mathrm{i}}=0.61 \mathrm{nM}\right)>\operatorname{VEVAD}\left(K_{\mathrm{i}}\right.$ $=3.7 \mathrm{nM})>\operatorname{VDIAD}\left(K_{\mathrm{i}}=4.5 \mathrm{nM}\right)$ etc. An approximate condition needed to be satisfied by the kinetic parameters (the Michaelis constant $-K_{\mathrm{M}}$ and the specificity constant $-k_{\text {cat }} / K_{\mathrm{M}}$ ) for competitive inhibition is reported. The estimated values of $k_{\mathrm{cat}} / K_{\mathrm{M}}$, being within the experimentally established range (between $10^{-4}$ and $10^{-1} \mu \mathrm{M}^{-1} \mathrm{~s}^{-1}$ ), indicate that VELAD and VDVAD are most specific to caspase-2. These two particular peptides are nearly 1.5, 3 and 4 times more specific to the receptor than VEIAD, VEVAD and VDIAD respectively. Additional kinetic threshold, aimed to discriminate tightly bound inhibitors, is given.
\end{abstract}

Keywords: Enzyme; human caspase-2; inhibition; peptide inhibitor; QM/MM; SCC-DFTB-D

\section{Introduction}

Homologues that make up the caspase (casp) family of cysteine proteases are essential mediators of cellular processes, such as apoptosis, proliferation, and differentiation. ${ }^{1,2}$ They are synthesized and stored as inactive zymogens, as well as divided into inflammatory (caspase-1, -4 , $-5,-12$ in humans and caspase- $1,-11$, and -12 in mice) and apoptotic (caspase- $3,-6,-7,-8$, and -9 in mammals) caspases according to their function and pro-domain structure. The functions of caspase-2, -10 , and -14 can not be easily categorized. Apoptotic caspases are further subclassified by their mechanism of action as initiators (caspase-8 and -9) and executioners (caspase- $3,-6$, and -7).

The first identified mammalian member is caspase- 2 and its physiological role is not quite clear. Caspase-2, one of the most evolutionarily conserved caspases, is inclined to behave as either executioner or initiator. In terms of substrate specificity, caspase- 2 is similar to caspase- 3 and -7 (executioner caspases). However, the long $\mathrm{N}$-terminal caspase recruitment domain (CARD) of caspase-2 indicates its potential role as an initiator caspase. ${ }^{3}$ While the function of caspase-2 in the embryonic development of mice is questionable, ${ }^{4}$ its important role in stress-induced cell death pathways and tumor suppression is more certain. ${ }^{5}$ The potential roles of caspase- 2 in mediating nonapoptotic pathways (cell-cycle regulation and DNA repair) have been reported in terms of whether caspase- 2 is mandatory for apoptosis under specific circumstances, ${ }^{6,7}$ or whether it primarily functions in cell-cycle regulation. ${ }^{5}$ An elevated expression level of caspase-2 has been observed in the brain of patients with some neurodegenerative disorders. ${ }^{8}$ In addition, the critical role of caspase-2 in mediating nonalcoholic steatohepatitis (NASH) pathogenesis, a chronic and aggressive liver condition not only in mice but probably in humans, has been highlighted. ${ }^{9}$ 
Whereas many questions on caspase- 2 physiology remain enigmatic, one of the key aspects for developing caspase-2 specific probes is related to the way in which caspase- 2 gets activated.

Peptide bonds are hydrolyzed using caspases (endoproteases) in a reaction that depends on catalytic cysteine residues in the caspase active site and occurs only after certain aspartic acid residues in the substrate. Besides resulting in substrate inactivation, caspase-mediated processing may generate active signaling molecules that participate in apoptosis and inflammation. Caspase activities are strictly regulated by protein-protein interactions and by proteolysis. ${ }^{1}$ The crystal structures of caspase- 2 in complex with several peptide inhibitors and comparison of the apo (substrate-free) and inhibited caspase- 2 structures have revealed a recognition via several discrete catalytic steps: (i) activation of caspase- 2 by breaking a nonconserved salt bridge between Glu217 (caspase-2 is the only human caspase with glutamate at position 217) and the invariant Arg378, (ii) formation of a catalytically competent conformation upon binding to a single substrate, and (iii) formation of the enzyme-substrate complex after having both active sites occupied by the substrate. ${ }^{10}$ Caspase- 2 has been suggested to uniquely prefer a penta-peptide rather than a tetra-peptide, as required for efficient cleavage by other caspases. ${ }^{10}$ To gain more complete insights into the caspase-2/peptide recognition and further facilitate the design of caspase-2 inhibitors, a hybrid QM/MM approach is employed in this work.

\section{Methods}

To obtain the initial atomic coordinates of the apo and inhibited caspase- 2 structures, the experimental structures were retrieved from the Research Collaboratory for Structural Bioinformatics (RCSB) Protein Data Bank (PDB): 3R7S.PDB (apo caspase-2), 3R6G.PDB (caspase-2/
VDVAD), 3R5J.PDB (caspase-2/ADVAD), 3R7B.PDB (caspase-2/DVAD), and 3R6L.PDB (T380A/VDVAD). ${ }^{10}$ The sequence of the penta-peptide inhibitor was varied using single point mutations generated by applying the Mutagenesis engine of PyMol-v0.99 to the experimental structure 3R6G.PDB in a backbone-dependent fashion. ${ }^{11}$

Before running QM/MM calculations, the systems were prepared using the Amber 11 suite of programs. ${ }^{12,13}$ The solute was prepared using the Amber11 utility program tLeap in association with the ff99sb force field. ${ }^{14}$ Every inhibitor was initially prepared by parameteryzing its atom types, charges, and connectivity in order to be treated as part of the solute. The molecular geometry was optimized by Gaussian 98 at the MP2/6-31G* level of theory. ${ }^{15}$ The molecular electrostatic potential was calculated by Gaussian 98 at the HF/6-31G* level of theory, ${ }^{15}$ while the atomic charges were derived by means of the RESP fitting technique, ${ }^{16}$ which is part of AmberTools 1.5. ${ }^{12,13}$ Remaining parameters were assigned from the General Amber Force Field (GAFF), ${ }^{17}$ being entirely compatible with the ff99sb macromolecular force field. ${ }^{14}$ Every solute was solvated using a $10 \AA\left(1 \AA=10^{-10} \mathrm{~m}\right)$ pad of TIP3P water molecules $(\approx 11500)$ and the counter ions $\mathrm{Na}^{+}$were added to neutralize each system. To remove clashes and bad contacts, two-stage geometric minimization was performed using the Sander module of Amber11. ${ }^{12,13}$ At the outset, the positions of the solute atoms were kept fixed, while the positions of the water atoms were minimized by gradually reducing an initial harmonic restraint of $2 \mathrm{kcal}$ $\mathrm{mol}^{-1} \AA^{-2}$ on all non-hydrogen non-water atoms via 5000 combined steepest descent (2500 steps) and conjugate gradient (2500 steps) minimization steps. Afterwards, the entire system was minimized without restrains by means of 10000 combined steepest descent (5000 steps) and conjugate gradient (5000 steps) minimization steps.

A two-layered hybrid approach was employed to assess the binding affinities within the caspase-2:peptide complexes. The outer layer of the complex (Figure 1) was

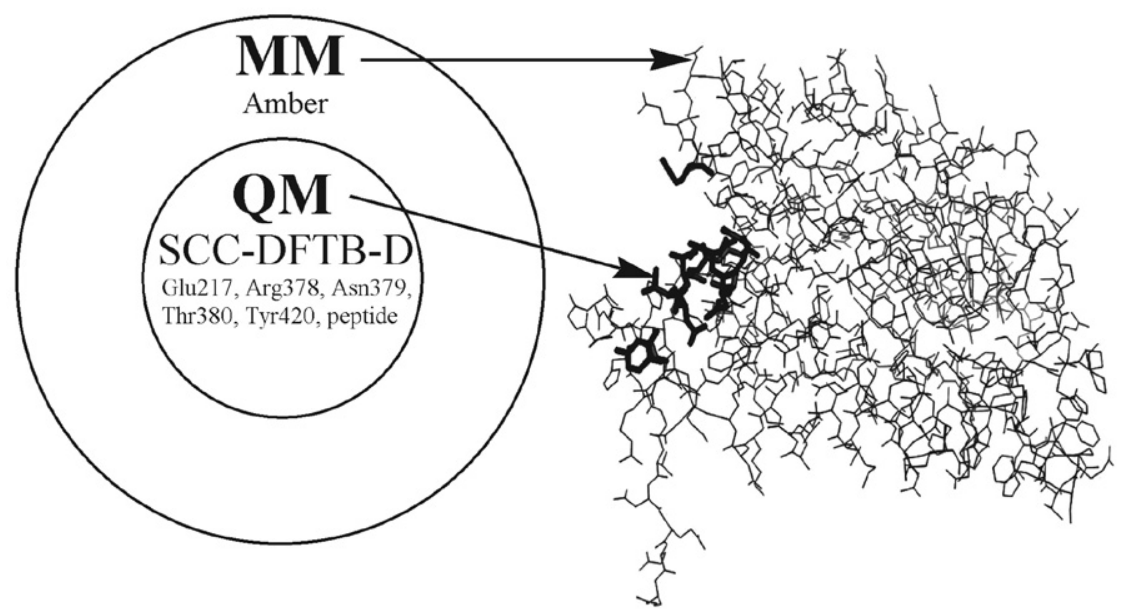

Figure 1. The two-layered QM/MM (SCC-DFTB-D/AMBER) model was used to evaluate the efficacy of peptide inhibitors towards caspase-2 (PDB ID: 3R6G). 
kept at the low level of theory (MM) with an Amber force field. The central layer of the complex (bold sticks; Figure 1) was treated at the high level of theory (QM), employing SCC-DFTB-D, the Self-Consistent-Charge DensityFunctional Tight-Binding method ${ }^{18,19}$ with Dispersion energy, ${ }^{20}$ as implemented in Amber11. ${ }^{21,22}$ The inclusion of the empirical correction for dispersion energy into SCCDFTB provided a balanced and reliable description of the interactions inside the systems. ${ }^{23}$ Pure Density Functional Theory (DFT) methods are known for their modest computational costs, but they are not able to adequately describe dispersive forces, especially within unconventional systems, ${ }^{24,25}$ as many density functionals are empirical. ${ }^{20}$ DFT was extended to include dispersion correction (DFT-D), ${ }^{26,27}$ and as such DFT-D became suitable for performing energy minimizations and vibrational analyses of extended molecular complexes containing hundreds of atoms. By being a few orders of magnitude faster than DFT-D, ${ }^{23,28-33}$ SCC-DFTB-D was suggested to be applicable to both quantumchemical simulations and calculations pertaining to a large number of extended molecular complexes. ${ }^{23}$

The total interaction energies were defined as:

$$
\Delta E_{\text {interaction }}=\Delta E_{\text {model,high }}+\Delta E_{\text {real, low }}-\Delta E_{\text {model, low }}
$$

where $\Delta E_{\text {model }}$ denote the energies of the model system defined at high and low level of theory and $\Delta E_{\text {real }}$ denotes the whole (real) system. Therefore, the equivalent binding free energies of the complex systems were determined as:

$$
\Delta G_{\text {binding }} \approx \Delta G=G_{\text {casp-2:peptide }}-\left[G_{\text {casp-2 }}+G_{\text {peptide }}\right]
$$

The thermodynamic quantities (enthalpies, entropies, and different entropic contributions) were obtained from frequency calculations done by the Nmode module of Amber 11. ${ }^{12,13}$ The different entropic contributions (translation, rotation, and vibration) for caspase-2:peptide complexes were calculated as:

$$
\Delta S=S_{\text {casp-2:peptide }}-\left[S_{\text {casp-2 }}+S_{\text {peptide }}\right]
$$

\section{Results and Discussion}

Kinetic measurements of competitive inhibition associated with the initial experimental structures ${ }^{10}$ are summarized in Table 1 . The specificity constant $\left(k_{\text {cat }} / K_{\mathrm{M}}\right)$ identified the penta-peptide VDVAD as a preferred inhibitor, while two residues, Thr380 and Tyr420, were identified as critical for recognizing a residue at the P5 position - the first position at the left end in the peptide sequence (Figures $2 \mathrm{~b} \& 2 \mathrm{c}$ ). The salt bridge between Glu217 and Arg378, which is present in the apo caspase-2 (3.37 $\AA$, Figure 2a), is broken in the caspase-2:VDVAD complex (8.05 Å, Figure 2b), because Thr380 and Tyr420 in P5 rec- ognition move 2.1 and $3.6 \AA$, respectively (Figure $2 \mathrm{~d}$ ). Furthermore, the specificity constant revealed that mutation of Thr380 to Ala reduces the catalytic efficiency of caspase- 2 by about 40 fold (Table 1), as Thr380Ala (Figure 2c) causes the loss of the hydrogen bond between Thr380 and the P5 side chain (3.51 $\AA$, Figure $2 \mathrm{~b}$ ) due to a $2.3 \AA$ movement in the main chain in residue 380 . Structurally speaking in a similar manner, mutation of Tyr420 to Ala reduces the catalytic efficiency of caspase- 2 by about 4 fold (Table 1), as Tyr420Ala causes a $0.5 \AA$ movement of the side chain of residue 420 and the loss of the hydrophobic interaction between Tyr420 and the P5 side chain. ${ }^{10}$

Table 1. Kinetic data ${ }^{10}$ for experimental caspase-2:peptide inhibitor

\begin{tabular}{|c|c|c|c|c|}
\hline $\begin{array}{l}\text { Complex }^{(\mathbf{a})} \\
\text { PDB ID }\end{array}$ & $\begin{array}{l}K_{M}(\mathbf{b}) \\
(\mu \mathrm{M})\end{array}$ & $\begin{array}{l}k_{\text {cat }} \\
\left(\mathrm{s}^{-1}\right)\end{array}$ & $\begin{array}{c}k_{\mathrm{cat}} / K_{\mathrm{M}} \\
\left(\mu \mathrm{M}^{-1} \mathrm{~s}^{-1}\right)\end{array}$ & $\begin{array}{c}I C_{50}(\mathrm{~b}),(\mathrm{c}) \\
(\mathrm{nM})\end{array}$ \\
\hline $\begin{array}{c}w t: \text { VDVAD } \\
\text { 3R6G }\end{array}$ & 25 & 0.60 & 0.024 & 25 \\
\hline $\begin{array}{c}\text { wt:ADVAD } \\
\text { 3R5J }\end{array}$ & 150 & 0.81 & 0.0055 & 110 \\
\hline $\begin{array}{c}\text { wt:DVAD } \\
\text { 3R7B }\end{array}$ & 92 & 0.12 & 0.0013 & 710 \\
\hline $\begin{array}{l}\text { Y420A:VDVAD } \\
\text { Y420A of 3R6G }\end{array}$ & 84 & 0.52 & 0.0062 & 314 \\
\hline $\begin{array}{l}\text { T380A:VDVAD } \\
\text { 3R6L }\end{array}$ & 220 & 0.13 & 0.00060 & 347 \\
\hline $\begin{array}{l}\text { T380A/Y420A:VDVAD } \\
\text { Y420A of 3R6L }\end{array}$ & $>400$ & $<0.000014$ & $4 \quad \mathrm{~N} / \mathrm{A}^{(\mathbf{d})}$ & 574 \\
\hline $\begin{array}{l}\text { (a) wild-type (wt) casp- } 2 \text {, } \\
\text { (b) } 1 \mu \mathrm{M}=10^{-6} \mathrm{M}, 1 \mathrm{nM} \\
\text { tion at which a substance } \\
\text { (d) It is unreliable to mea } \\
\text { slowest }\left(k_{\text {cat }} / K_{\mathrm{M}}<10^{-4} \mu \mathrm{N}\right. \\
\text { reactions. }{ }^{36}\end{array}$ & $\begin{array}{l}\text { Ala (A), } \\
=10^{-9} \mathrm{M} \\
\text { exerts ha } \\
\text { sure the }\end{array}$ & $\begin{array}{l}\text { Asp }(\mathrm{D}) \text {, Thr } \\
\text { (c) } I C_{50} \text { repre } \\
\text { alf of its maxi } \\
\text { catalytic effic } \\
\text { nd fastest }\left(k_{\text {cat }}\right.\end{array}$ & $\begin{array}{l}r(\mathrm{~T}), \text { Tyr }(\mathrm{Y}) \\
\text { resents the co } \\
\text { imal inhibito } \\
\text { iciency value } \\
\text { at } / K_{\mathrm{M}}>10^{-1}\end{array}$ & $\begin{array}{l}\text {, Val }(\mathrm{V}) \\
\text { ncentra- } \\
\text { ry effect. } \\
\text { s for the } \\
\left.\mathrm{AM}^{-1} \mathrm{~s}^{-1}\right)\end{array}$ \\
\hline
\end{tabular}
complexes: $K_{\mathrm{M}}-$ Michaelis constant, $k_{\text {cat }}-$ catalytic constant, $k_{\text {cat }} /$ $K_{\mathrm{M}}$ - specificity constant, and $I C_{50}$ - inhibitory concentration

To perform physically realistic QM/MM calculations, the first important aspect is how to define a QM region, or what caspase- 2 residues need to be included in the QM region. There are no good universal rules here. Binding site residues of caspase- 2 that are involved in noncovalent interactions with a peptide inhibitor are: Arg219, His277, Gly278, Gln318, Cys320, Ala376, Arg378, Asn379, Thr380, Trp385, Arg417, Glu418, and Tyr420. ${ }^{10}$ Caspase-2 is the only human caspase with glutamate at position 217 forming a salt bridge with Arg378 in the apo caspase-2 (Figure 2a). The inhibition of caspase-2 was related to breaking the Glu217-Arg378 salt bridge, while residues Thr380 and Tyr420 were pointed out as the key elements for recognizing a preferred penta-peptide along a catalytic pathway (Figure 2b). ${ }^{10}$ An intention to define a QM region to mimic the active site has to take into account all these experimental and structural arguments. Knowing that inclusion of a different number of caspase- 2 residues in the $\mathrm{QM}$ region is associated with different thermodynamic 
a)

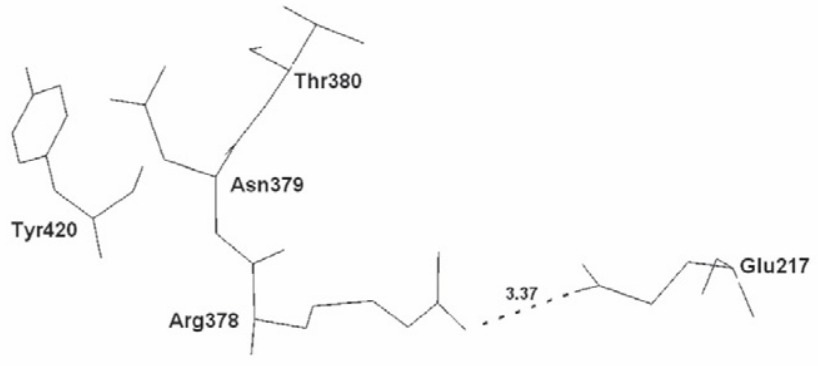

b)

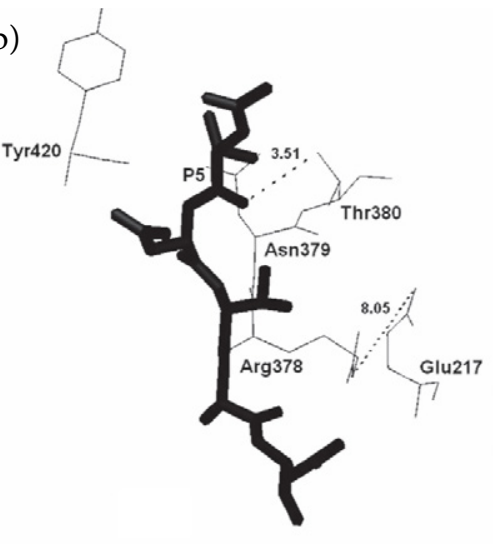

c)

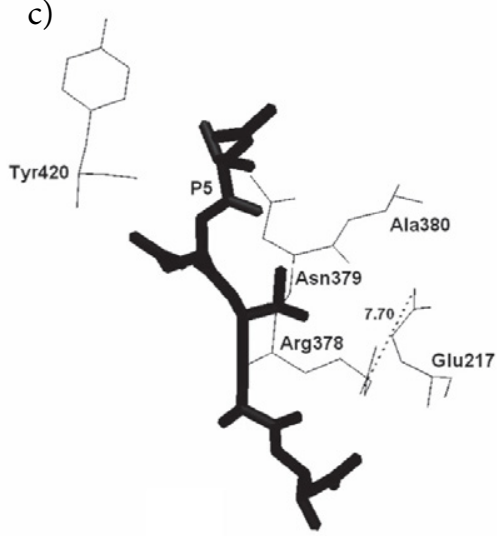

d)

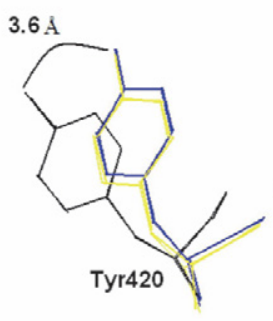

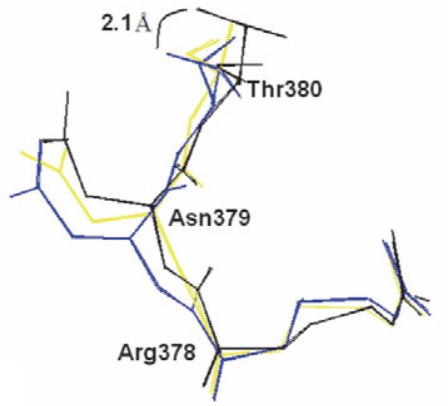

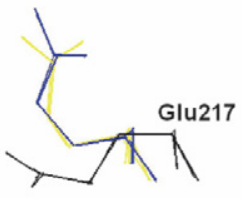

Figure 2. QM region is based upon some important experimental facts ${ }^{10}$ associated with caspase-2/peptide recognition: (a) apo (ligand-free)

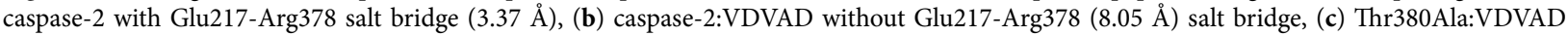
without Glu217-Arg378 (7.70 $\AA$ ) salt bridge, and (d) the overlay of the enzyme residues of apo caspase-2 (black), caspase-2:VDVAD (blue), and Thr380Ala:VDVAD (yellow). VDVAD is denoted by bold sticks in (b) and (c), P5 - the first position at the left end in the peptide sequence.

Table 2. Binding free energies that are evaluated using QM/MM (SCC-DFTB-D/AMBER) method for experimental caspase-2:peptide structures

\begin{tabular}{|c|c|c|c|c|c|c|}
\hline $\begin{array}{l}\text { Complex }^{(a)} \\
\text { PDB ID }\end{array}$ & $\begin{array}{c}\Delta G_{\text {bind }}{ }^{(b)} \\
\left(\mathrm{kcal} \mathrm{mol}^{-1}\right)\end{array}$ & $\begin{array}{c}\Delta H \\
\left(\text { kcal mol}^{-1}\right)\end{array}$ & $\begin{array}{c}T \Delta S_{\text {total }} \\
\left(\mathrm{kcal} \mathrm{mol}^{-1}\right)\end{array}$ & $\begin{array}{c}T \Delta S_{\text {trans }} \\
\left(\mathrm{kcal} \mathrm{mol}^{-1}\right)\end{array}$ & $\begin{array}{c}T \Delta S_{\text {rot }} \\
\left(\mathrm{kcal} \mathrm{mol}^{-1}\right)\end{array}$ & $\begin{array}{c}T \Delta S_{\mathrm{vib}} \\
\left(\mathrm{kcal} \mathrm{mol}^{-1}\right)\end{array}$ \\
\hline $\begin{array}{l}\text { wt:VDVAD } \\
\text { 3R6G }\end{array}$ & -13.22 & -31.85 & -18.63 & -12.90 & -10.61 & 4.88 \\
\hline $\begin{array}{l}\text { wt:ADVAD } \\
\text { 3R5J }\end{array}$ & -9.83 & -30.35 & -20.52 & -12.87 & -10.56 & 2.91 \\
\hline $\begin{array}{l}\text { Y420A:VDVAD } \\
\text { Y420A of 3R6G }\end{array}$ & -9.17 & -30.29 & -21.12 & -12.87 & -10.38 & 2.13 \\
\hline $\begin{array}{l}\text { T380A:VDVAD } \\
\text { 3R6L }\end{array}$ & -8.71 & -29.74 & -21.03 & -12.90 & -10.80 & 2.67 \\
\hline $\begin{array}{l}\text { T380A/Y420A:VDVAD } \\
\text { Y420A of 3R6L }\end{array}$ & -5.53 & -25.69 & -20.16 & -12.81 & -10.53 & 3.18 \\
\hline $\begin{array}{l}\text { wt:DVAD } \\
\text { 3R7B }\end{array}$ & -2.75 & -24.28 & -21.53 & -12.81 & -10.58 & 1.86 \\
\hline
\end{tabular}

(a) wild-type (wt) casp-2, Ala (A), Asp (D), Thr (T), Tyr (Y), Val (V) ${ }^{(b)}$ Gibb's free energy $(\Delta G)$, enthalpy $(\Delta H)$, entropy $(T \Delta S)$ and entropic contribution, translational $\left(T \Delta S_{\text {trans }}\right)$, rotational $\left(T \Delta S_{\text {rot }}\right)$, vibrational $\left(T \Delta S_{\text {vib }}\right)$ are derived from Eqs. 2 and 3. 
properties such as the binding free energies means that an appropriate QM region is supposed to generate results in agreement with experimental data. Even though one might want to have as large a QM region as possible, having more than 80-100 atoms in a QM region lead to simulations that are computationally very expensive. ${ }^{12,13}$ To reconcile all the structural, functional, and computational standpoints as much as possible, the present choice of including Glu217, Arg378, Asn379, Thr380, Tyr420, and the peptide inhibitor in the QM region (Figure 1) is carefully made in order to

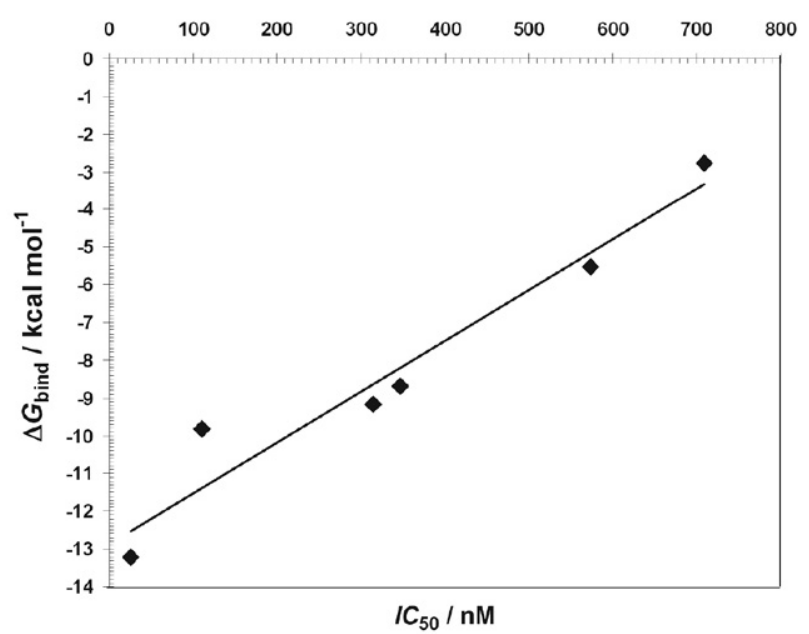

Figure 3. Correlation of the calculated binding free energy $\left(\Delta G_{\text {bind }}\right)$ with the measured inhibitory concentration $\left(I C_{50}\right)$ for the experimental caspase-2:peptide structures. $\Delta G_{\text {bind }}=0.013 I C_{50}-12.85, R$ $=0.97$. generate the inhibition constants that are within an experimental range - from $1 \mu \mathrm{M}\left(1 \mu \mathrm{M}=10^{-6} \mathrm{M}\right)$ to $0.01 \mathrm{nM}(1$ $\left.\mathrm{nM}=10^{-9} \mathrm{M}\right)$ for inhibited caspase-2 structures. ${ }^{34}$

QM/MM binding free energies for the experimental structures are given in Table 2. Figure 3 shows quite a satisfactory linear correlation between the calculated $\Delta G_{\text {bind }}$ (Table 2) and the experimental inhibitory concentration $I C_{50}$ (Table 1): $\Delta G_{\text {bind }}=0.013 I C_{50}-12.85, R=0.97$. The most negative BFE for the caspase-2:VDVAD complex $\left(-13.22 \mathrm{kcal} \mathrm{mol}^{-1}\right)$ signifies that VDVAD is a favorable inhibitor. The enthalpy contribution $(\Delta H)$ for the complexes ranges from -31.85 to $-24.28 \mathrm{kcal} \mathrm{mol}^{-1}$, indicating that the noncovalent complexation process is exothermic. In case of the entropy contribution $(T \Delta S)$, the less negative entropy change is, the more reduced degrees of freedom of an inhibitor in the protein active pocket are. The least negative entropy $\left(-18.63 \mathrm{kcal} \mathrm{mol}^{-1}\right)$ is associated with caspase-2:VDVAD, of which vibrational contribution (4.88 $\mathrm{kcal} \mathrm{mol}^{-1}$ ) makes a most conspicuous difference with respect to the other complexes (Table 2). The increased and thermodynamically favorable vibrational entropy change upon binding of VDVAD to caspase- 2 is the signature of preferred noncovalent complexation.

To search for more effective penta-peptides, the sequence of VDVwAD is systematically varied by means of single point mutations of its constitutive residues. To make such a procedure consistent, each amino acid is mutated to its counterpart observed from a physicochemical standpoint. Val (V), an aliphatic and hydrophobic amino acid, is mutated to either Ile (I) or Leu (L). Asp (D), a polar and

Table 3. QM/MM binding free energies that are within experimental range (between -8.23 and $-15.09 \mathrm{kcal} \mathrm{mol}^{-1}$ ) for caspase-2:peptide complexes

\begin{tabular}{|c|c|c|c|c|}
\hline Complex $^{(\mathbf{a})}$ & $\begin{array}{c}\Delta G_{\text {bind }}{ }^{(b)} \\
\left(\mathrm{kcal} \mathrm{mol}^{-1}\right)\end{array}$ & $\begin{array}{c}\Delta H \\
\left(\mathrm{kcal} \mathrm{mol}^{-1}\right)\end{array}$ & $\begin{array}{c}T \Delta S_{\text {total }} \\
\left(\mathrm{kcal} \mathrm{mol}^{-1}\right)\end{array}$ & $\begin{array}{l}K_{\mathrm{i}}^{(\mathbf{b})} \\
(\mu \mathrm{M})\end{array}$ \\
\hline casp-2:VELAD & -13.84 & -33.49 & -19.65 & 0.000081 \\
\hline casp-2:VDVAD & -13.22 & -31.85 & -18.63 & 0.00023 \\
\hline casp-2:VEIAD & -12.64 & -30.91 & -18.27 & 0.00061 \\
\hline casp-2:VEVAD & -11.57 & -29.60 & -18.03 & 0.0037 \\
\hline casp-2:VDIAD & -11.45 & -32.75 & -21.30 & 0.0045 \\
\hline casp-2:VDLAE & -11.09 & -29.12 & -18.03 & 0.0083 \\
\hline casp-2:IEIAD & -10.85 & -26.60 & -15.75 & 0.012 \\
\hline casp-2:IDVAD & -10.72 & -29.35 & -18.63 & 0.015 \\
\hline casp-2:LDIAD & -10.54 & -31.87 & -21.33 & 0.021 \\
\hline casp-2:VDLGE & -10.52 & -28.82 & -18.30 & 0.022 \\
\hline casp-2:VEIGE & -10.21 & -29.29 & -19.08 & 0.036 \\
\hline casp-2:IDLAD & -10.07 & -29.96 & -19.89 & 0.045 \\
\hline casp-2:IEIGE & -10.01 & -33.26 & -23.25 & 0.050 \\
\hline casp-2:IDIAD & -9.80 & -29.63 & -19.83 & 0.072 \\
\hline casp-2:LELAD & -9.75 & -32.91 & -23.16 & 0.078 \\
\hline casp-2:VELGE & -9.33 & -28.38 & -19.05 & 0.16 \\
\hline casp-2:VDLAD & -9.27 & -29.52 & -20.25 & 0.17 \\
\hline casp-2:LELAE & -8.55 & -29.13 & -20.58 & 0.59 \\
\hline
\end{tabular}

(a) Ala (A), Asp (D), Glu (E), Ile (I), Leu (L), Val (V) ${ }^{(\mathbf{b})}$ Gibb's free energy $(\Delta G)$, enthalpy $(\Delta H)$ entropy $(T \Delta S)$, inhibition constant $\left(K_{\mathrm{i}}\right), \Delta G_{\text {bind }}=R T \ln \left(K_{\mathrm{i}}\right), R$ - the gas constant $\left(1.9872 \mathrm{kcal} \mathrm{K}^{-1}\right.$ $\left.\mathrm{mol}^{-1}\right), T$ - the absolute temperature (300 K), $1 \mu \mathrm{M}=10^{-6} \mathrm{M}$ 

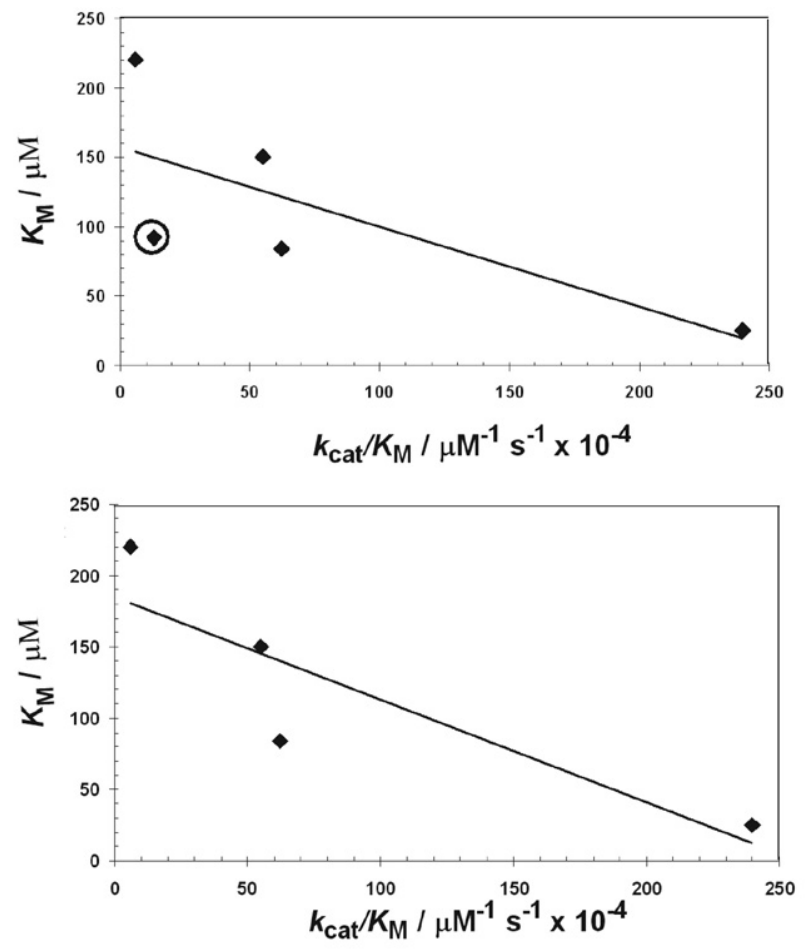

Figure 4. Correlation of the Michaelis constant $\left(K_{\mathrm{M}}\right)$ with the specificity constant $\left(k_{\text {cat }} / K_{\mathrm{M}}\right)$ for the experimental caspase-2:peptide structures: $K_{\mathrm{M}}=-0.58 k_{\text {cat }} / K_{\mathrm{M}}+157.51, R=0.74$ (top). If a data point (denoted by circle, top) is removed, the correlation becomes: $K_{\mathrm{M}}=-0.72 k_{\text {cat }} / K_{\mathrm{M}}+184.99, R=0.88$ (bottom).

negatively charged amino acid, is mutated to Glu (E). Ala (A), a tiny and hydrophobic amino acid, is mutated to Gly (G). The estimated BFE and $K_{\mathrm{i}}$ for each generated complex are reported in Table S1 (Supplementary Material). On the basis of the relation $\Delta G_{\text {bind }}=R T \ln \left(K_{\mathrm{i}}\right)(R$ - the gas constant $\left.=1.9872 \mathrm{kcal} \mathrm{K}^{-1} \mathrm{~mol}^{-1}\right), T-$ the absolute temperature $=300 \mathrm{~K})$, the experimental range of $K_{\mathrm{i}}$ in between 1 $\mu \mathrm{M}$ and $0.01 \mathrm{nM}$ corresponds to the $\operatorname{BFE}\left(\Delta G_{\text {bind }}\right)$ range in between -8.23 and $-15.09 \mathrm{kcal} \mathrm{mol}^{-1}$ for inhibited caspase-2 structures. Numerical inspection of the data in Table $\mathrm{S} 1$ identified the complexes that have the BFEs inside of this specific range (Table 3). Thus, as far as affinity issue for the receptor is concerned, the order of preferred inhibitors is: $\operatorname{VELAD}\left(K_{\mathrm{i}}=0.081 \mathrm{nM}\right)>\operatorname{VDVAD}\left(K_{\mathrm{i}}=0.23 \mathrm{nM}\right)$ $>\operatorname{VEIAD}\left(K_{\mathrm{i}}=0.61 \mathrm{nM}\right)>\operatorname{VEVAD}\left(K_{\mathrm{i}}=3.7 \mathrm{nM}\right)>$ $\operatorname{VDIAD}\left(K_{\mathrm{i}}=4.5 \mathrm{nM}\right)$ etc.

In order to evaluate the specificity constant for the complexes (Table 3), the correlation of the Michaelis constant with the specificity constant for the experimental caspase-2:peptide structures (Table 1) is observed. Even though two linear correlations are established (Figure 4), the first one $\left(K_{\mathrm{M}}=-0.58 k_{\mathrm{cat}} / K_{\mathrm{M}}+157.51, R=0.74\right.$; Figure 4 , top) is slightly more suitable because it reproduces the experimental value of the specificity constant for the caspase-2:VDVAD complex more accurately than the second one (Figure 4, bottom). Due to the negative slope $(-0.58)$ of the linear regression line, $K_{\mathrm{M}}<157.51 \mu \mathrm{M}$ rep-

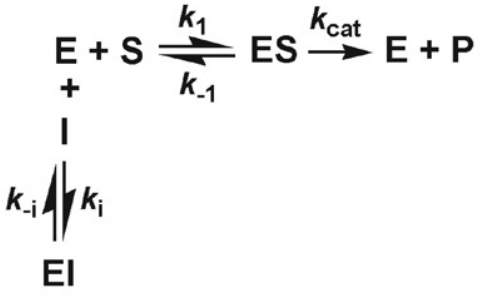

Figure 5. Reaction of competitive inhibition. ${ }^{35}$

resents an approximate condition for the physically meaningful estimate of $k_{\text {cat }} / K_{\mathrm{M}}$.

To evaluate the functional efficiency of the complexes (Table 3 ) in terms of the specificity constant $\left(k_{\text {cat }} / K_{\mathrm{M}}\right)$, a competitive inhibition mechanism is considered (Figure 5). For such a reaction, the inhibition constant is defined as:

$$
K_{\mathrm{i}}=\frac{I C_{50}}{\left(\frac{[S]}{K_{\mathrm{M}}}+1\right)}=\left\{\begin{array}{l}
\text { if }[S]=K_{\mathrm{M}}, K_{\mathrm{i}}=I C_{50} / 2 \\
\text { if }[S] \gg>K_{\mathrm{M}}, K_{\mathrm{i}}<<I C_{50} \\
\text { if }[S]<<K_{\mathrm{M}}, K_{\mathrm{i}} \cong I C_{50}
\end{array}\right\}
$$

where $I C_{50}$ is the inhibitory concentration, $K_{\mathrm{M}}$ is the Michaelis constant, and $[S]$ is the substrate concentration. ${ }^{35}$ Solving Eq. 4 for the Michaelis constant gives:

$$
K_{\mathrm{M}}=\frac{[S]}{\left(\frac{I C_{50}}{K_{\mathrm{i}}}-1\right)}
$$

The kinetic data are analyzed as follows. $I C_{50}$ is evaluated using its linear correlation with $\Delta G_{\text {bind }}$ (Figure 3). $K_{\mathrm{M}}$ is evaluated using Eq. 5 with $[S] \approx 2.7 \mathrm{mM}(1 \mathrm{mM}=$ $\left.10^{-3} \mathrm{M}\right)$ - a typical experimental value. ${ }^{10}$ Of these complexes (Table 3 ), those having $K_{\mathrm{M}}<157.51 \mu \mathrm{M}$ are selected (Table 4 ) and may be considered as competitively inhibited structures. The comparison of the values of $K_{\mathrm{M}}$ (Table 4) with respect to $[S]$ shows that $[S]>>K_{\mathrm{M}}$, what is in line with $K_{\mathrm{i}}<<I C_{50}$ according to Eq. 4 . The estimate of $k_{\text {cat }} /$ $K_{\mathrm{M}}$ (Table 4 ) is made by way of the linear correlation $K_{\mathrm{M}}=$ $-0.58 k_{\text {cat }} / K_{\mathrm{M}}+157.51$ (Figure 4 , top). The specificity constants $\left(k_{\mathrm{cat}} / K_{\mathrm{M}}\right)$ are within the experimental range (between $10^{-4}$ and $\left.10^{-1} \mu \mathrm{M}^{-1} \mathrm{~s}^{-1}\right),{ }^{36}$ indicating that VELAD and VDVAD are most specific to caspase-2. These two particular peptides are approximately 1.5, 3 and 4 times more specific to the enzyme than VEIAD, VEVAD and VDIAD respectively.

In case of simple enzyme reaction with one substrate, if $k_{\text {cat }}<<k_{-1}, K_{\mathrm{M}}$ is conceivable as the dissociation constant that quantifies the strength of the ES complex formation. If the $K_{\mathrm{M}}$ value gets smaller then the ES complex gets stronger (or more stable). In other words, the more pronounced enzyme affinity to the substrate is lined up with the more specific inhibition of the enzyme. The values of $\Delta G_{\text {bind }}$ (Table 3 ), $K_{\mathrm{M}}$ (Table 4 ) and $k_{\text {cat }} / K_{\mathrm{M}}$ (Table 4 ) conform to the trend. 
Table 4. Evaluated competitive inhibition data for caspase-2:peptide complexes: $K_{\mathrm{i}}$ - inhibition constant, $I C_{50}-$ inhibitory concentration, $K_{\mathrm{M}}-$ Michaelis constant, $k_{\text {cat }}-$ catalytic constant, and $k_{\text {cat }} / K_{\mathrm{M}}-$ specificity constant

\begin{tabular}{|c|c|c|c|c|c|c|}
\hline Complex $^{(a)}$ & $\Delta G_{\text {bind }}\left(\mathrm{kcal} \mathrm{mol}^{-1}\right)$ & $K_{\mathrm{i}}(\mu \mathrm{M})^{(\mathbf{b})}$ & $I C_{50}(\mathrm{nM})^{(\mathrm{b})}$ & $K_{\mathrm{M}}(\mu \mathrm{M})^{(\mathbf{b}),(\mathrm{c})}$ & $k_{\text {cat }}\left(\mathrm{s}^{-1}\right)$ & $k_{\text {cat }} / K_{M}\left(\mu M^{-1} s^{-1}\right)$ \\
\hline casp-2:VELAD & -13.84 & 0.000081 & 23.88 & 9.19 & 0.24 & 0.026 \\
\hline casp-2:VDVAD & -13.22 & 0.00023 & 25.00 & 25.00 & 0.58 & 0.023 \\
\hline casp-2:VEIAD & -12.64 & 0.00061 & 26.15 & 64.48 & 1.03 & 0.016 \\
\hline casp-2:VEVAD & -11.57 & 0.0037 & 98.46 & 105.43 & 0.94 & 0.0089 \\
\hline casp-2:VDIAD & -11.45 & 0.0045 & 107.69 & 117.75 & 0.80 & 0.0068 \\
\hline
\end{tabular}

(a) Ala (A), Asp (D), Glu (E), Ile (I), Leu (L), Val (V) ${ }^{(\mathbf{b})} 1 \mu \mathrm{M}=10^{-6} \mathrm{M}, 1 \mathrm{nM}=10^{-9} \mathrm{M}^{\text {(c) }}$ Of the complexes given in Table 3, those having $K_{\mathrm{M}}<$ $157.51 \mu \mathrm{M}$ are reported here. $K_{\mathrm{M}}<157.51 \mu \mathrm{M}$ is an approximate condition for the physically meaningful estimate of $k_{\text {cat }} / K_{\mathrm{M}}$ (Figure 4 , top).

For tightly bound inhibitors, the inhibition constant is:

$$
K_{\mathrm{i}}=\frac{\left(I C_{50}-[E] / 2\right)}{\left(\frac{[S]}{K_{\mathrm{M}}}+1\right)}
$$

where $[E]$ is the enzyme concentration. ${ }^{35}$ For tightly bound inhibitors, the equation 6 takes into account the larger amounts of inhibitor bound species, thus making that the Michaelis-Menten assumption of the total enzyme concentration being equal does not hold. ${ }^{35,37}$

The Michaelis constant for tightly bound inhibitors is:

$$
K_{\mathrm{M}}=\frac{[S]}{\left(\frac{I C_{50}-[E] / 2}{K_{\mathrm{i}}}-1\right)}
$$

The condition $K_{\mathrm{M}}<157.51 \mu \mathrm{M}$ for tightly bound peptides means:

$$
\frac{[S]}{\left(\frac{I C_{50}-[E] / 2}{K_{\mathrm{i}}}-1\right)}<157.51 \mu \mathrm{M}
$$

Therefore,

$$
\frac{I C_{50}-[E] / 2}{K_{\mathrm{i}}}-1>\frac{[S]}{157.51}
$$

Solving Eq. 9 for $I C_{50}$ gives:

$$
I C_{50}>\frac{[S]}{157.51} K_{\mathrm{i}}+[E] / 2
$$

For $[S] \approx 2.7 \mathrm{mM}$ and $[E] \approx 50 \mathrm{nM}$ - typical experimental values, ${ }^{10} \mathrm{Eq} .10$ gives an approximate condition, $I C_{50}(\mathrm{nM})>17.14 K_{\mathrm{i}}(\mathrm{nM})+25$, which should be satisfied by the tight binding of penta-peptides to caspase- 2 . The values of $I C_{50}$ and $K_{\mathrm{i}}$ (Table 4 ) indicate that VEVAD and VDIAD satisfy this condition. By reducing $[E]$ from 50 to $44.8 \mathrm{nM}$, the condition becomes $I C_{50}(\mathrm{nM})>17.14 K_{\mathrm{i}}$ $(\mathrm{nM})+22.4$ and is satisfied by VELAD, VEVAD and VDIAD. If [E] is additionally lowered to $42 \mathrm{nM}$ then the condition gets $I C_{50}(\mathrm{nM})>17.14 K_{\mathrm{i}}(\mathrm{nM})+21$, indicating that VELAD, VDVAD, VEVAD and VDIAD may be considered as tightly bound inhibitors.

In most experimental investigations of enzyme kinetics, the total concentration of substrate is in excess of the enzyme concentration, thus making the free and total substrate concentrations essentially equal. ${ }^{35}$ For a set of inhibitor candidates, comparison of $K_{\mathrm{M}}$ or $I C_{50}$ values is only assumed to be valid when these values are evaluated under identical experimental conditions. ${ }^{35,38}$ Only few data exist on the catalytic efficiencies of caspase substrates, so that a more complete understanding of their true substrate preferences is impossible. ${ }^{36}$ The present results are imagined to facilitate additional experiments, which are needed to understand better the kinetics of caspase-2/peptide recognition for further research or therapeutic product development. The fact that caspase inhibition-based drug has not been approved on the market so far means that the development of therapeutic approaches that specifically target caspases is a substantial challenge of particular biological and clinical interest. ${ }^{39}$

\section{Conclusions}

QM/MM model derived and exploited in this work has been shown to correlate with the existing experimental observations to an appreciable extent, indicating that caspase- 2 uniquely prefers a penta-peptide such as VDVAD.

This approach has enabled the extensive and systematic investigations of some of the important aspects both of the thermodynamics and of the kinetics of caspase- 2 recognition by a large number of penta-peptides. The sequence of VDVAD has been consistently varied and the corresponding binding free energies with the inhibition constants have been evaluated. The values of the inhibition constants, being within the experimental range for several caspase-2:peptide complexes, have indicated that the affinity order is: VELAD > VDVAD > VEIAD > VEVAD > VDIAD etc. The specificity constants for competitive inhibition have been estimated to fit the experimentally predicted range, thereby suggesting that VELAD and VDVAD are most specific to caspase-2; also both are about 1.5, 3 and 4 times more specific to the receptor than VEIAD, VEVAD and VDIAD respectively. An approximate kinetic 
threshold, supposed to discriminate tightly bound peptide inhibitors, has been reported.

This study has demonstrated that a well-calibrated computational work may yield information inaccessible by other methods or suggest new experimental procedures.

\section{Acknowledgment}

Prof. David A. Case of Rutgers University is acknowledged for granting the author an academic license for using the molecular dynamics software package Amber11 in combination with AmberTools 1.5.

\section{Supplementary Material}

QM/MM binding free energies for all studied caspase-2:peptide complexes are available.

\section{References}

1. D. R. Mcllwain, T. Berger, T. W. Mak, Cold Spring Harb. Perspect. Biol. 2013, 5, a008656. DOI:10.1101/cshperspect.a008656

2. S. Nagata, Annu. Rev. Immunol. 2018, 36, 489-517.

DOI:10.1146/annurev-immunol-042617-053010

3. G. Krumschnabel, B. Sohm, F. Bock, C. Manzl, A. Villunger, Cell Death Differ. 2009, 16, 195-207.

DOI:10.1038/cdd.2008.170

4. L. Bergeron, G. I. Perez, G. Macdonald, L. Shi, Y. Sun, A. Jurisicova, S. Varmuza, K. E. Latham, J. A. Flaws, J. C. Salter, H. Hara, M. A. Moskowitz, E. Li, A. Greenberg, J. L. Tilly, J. Yuan, Genes Dev. 1998, 12, 1304-1314. DOI:10.1101/gad.12.9.1304

5. L. Bouchier-Hayes, J. Cell. Mol. Med. 2010, 14, 1212-1224. DOI:10.1111/j.1582-4934.2010.01037.x

6. S. Kumar, Nat. Rev. Cancer 2009, 9, 897-903.

DOI:10.1038/nrc2745

7. H. Vakifahmetoglu-Norberg, B. Zhivotovsky, Trends Cell Biol. 2010, 20, 150-159. DOI:10.1016/j.tcb.2009.12.006

8. S. Shimohama, H. Tanino, S. Fujimoto, Biochem. Biophys. Res. Commun. 1999, 256, 381-384. DOI:10.1006/bbrc.1999.0344

9. J. Y. Kim, R. Garcia-Carbonell, S. Yamachika, P. Zhao, D. Dhar, R. Loomba, R. J. Kaufman, A. R. Saltiel, M. Karin, Cell 2018, 75(1), 133-145.e15. DOI:10.1016/j.cell.2018.08.020

10. Y. Tang, J. A. Wells, M. R. Arkin, J. Biol. Chem. 2011, 286(39), 34147-34154. DOI:10.1074/jbc.M111.247627

11. PyMol, Version 0.99, W. L. DeLano, DeLano Scientific LLC, South San Francisco CA, 2006.

12. D. A. Case, T. Cheatham, T. Darden, H. Gohlke, R. Luo, K. M. Jr. Merz, A. Onufriev, C. Simmerling, B. Wang, R. Woods, J. Comput. Chem. 2005, 26, 1668-1688. DOI:10.1002/jcc.20290

13. Amber 11, D. A. Case, T. A. Darden, T. E. Cheatham III, C. L. Simmerling, J. Wang, R. E. Duke, R. Luo, R. C. Walker, W. Zhang, K. M. Merz, B. P. Roberts, B. Wang, S. Hayik, A. Roitberg, G. Seabra, I. Kolossváry, K. F. Wong, F. Paesani, J. Vanicek, J. Liu, X. Wu, S. R. Brozell, T. Steinbrecher, H. Gohlke, Q. Cai, X. Ye, J. Wang, M. J. Hsieh, G. Cui, D. R. Roe, D.
H. Mathews, M. G. Seetin, C. Sagui, V. Babin, T. Luchko, S. Gusarov, A. Kovalenko, and P. A. Kollman, University of California, San Francisco CA. 2010.

14. V. Hornak, R. Abei, A. Okur, B. Strockbine, A. Roitberg, C. Simmerling, Proteins 2006, 65, 712-725.

DOI: $10.1002 /$ prot. 21123

15. Gaussian 98, Revision A.9, M. J. Frisch, G. W. Trucks, H. B. Schlegel, G. E. Scuseria, M. A. Robb, J. R. Cheeseman, V. G. Zakrzewski, J. A. Montgomery, R. E. Stratmann, J. C. Burant, S. Dapprich, J. M. Millam, A. D. Daniels, K. N. Kudin, M. C. Strain, O. Farkas, J. Tomasi, V. Barone, M. Cossi, R. Cammi, B. Mennucci, C. Pomelli, C. Adamo, S. Clifford, J. Ochterski, G. A. Petersson, P. Y. Ayala, Q. Cui, K. Morokuma, D. K. Malick, A. D. Rabuck, K. Raghavachari, J. B. Foresman, J. Cioslowski, J. V. Ortiz, A. G. Baboul, B. Stefanov, G. Liu, A. Liashenko, P. Piskorz, I. Komaromi, R. Gomperts, R. L. Martin, D. J. Fox, T. A. Keith, M. A. Al-Laham, C. Y. Peng, A. Nanayakkara, M. Challacombe, P. M. W. Gill, B. Johnson, W. Chen, M. W. Wong, J. L. Andres, C. Gonzalez, M. Head-Gordon, E. S. Replogle, and J. A. Pople, Gaussian, Inc., Pittsburgh PA, 1998.

16. C. I. Bayly, P. Cieplak, W. Cornell, P. A. Kollman, J. Phys Chem. 1993, 97, 10269-10280. DOI:10.1021/j100142a004

17. J. Wang, R. M. Wolf, J. W. Caldwell, P. A. Kollman, D. A. Case, J. Comput. Chem. 2004, 25, 1157-1174.

DOI:10.1002/jcc.20035

18. M. Elstner, D. Porezag, G. Jungnickel, J. Elsner, M. Haugk, T. Frauenheim, S Suhai, G. Seifert, Phys. Rev. B 1998, 58, 72607268. DOI:10.1103/PhysRevB.58.7260

19. M. Elstner, P. Hobza, T. Frauenheim, S. Suhai, E. Kaxiras, J. Chem. Phys. 2001, 114, 5149-5155. DOI:10.1063/1.1329889

20. S. Grimme, J. Antony, T. Schwabe, C. Muck-Lichtenfeld, Org. Biomol. Chem. 2007, 5, 741-758. DOI:10.1039/B615319B

21. G. M. Seabre, R. C. Walker, M. Elstner, D. A. Case, A. E. Roitberg, J. Phys. Chem. A 2007, 111(26), 5655-5664. DOI:10.1021/jp0700711

22. R. C. Walker, M. F. Crowley, D. A. Case, J. Comp. Chem. 2008, 29(7), 1019-1031. DOI:10.1002/jcc.20857

23. T. Kubar, P. Jurecka, J. Cerny, J. Rezac, M. Otyepka, H. Valdes, P. Hobza, J. Phys. Chem. A 2007, 111, 5642-5647. DOI:10.1021/jp068858j

24. S. Kristyan, P. Pulay, Chem. Phys. Lett. 1994, 229, 175-180. DOI:10.1016/0009-2614(94)01027-7

25. P. Hobza, J. Sponer, T. Reschel, J. Comp. Chem. 1995, 16, 1315-1325. DOI:10.1002/jcc.540161102

26. P. Jurecka, J. Sponer, J. Cerny, P. Hobza, Phys. Chem. Chem. Phys. 2006, 8, 1985-1993. DOI:10.1039/B600027D

27. P. Jurecka, J. Cerny, P. Hobza, D. R. Salahub, J. Comp. Chem. 2007, 28, 555-569. DOI:10.1002/jcc.20570

28. A. Pavlov, P. M. Mitrasinovic, Curr. Org. Chem. 2010, 14, 129-138. DOI:10.2174/138527210790069866

29. P. M. Mitrasinovic, Curr. Drug Targ. 2013, 14, 817-829. DOI:10.2174/1389450111314070009

30. P. M. Mitrasinovic, Med. Chem. 2014, 10, 46-58. DOI:10.2174/157340641001131226122124

31. P. M. Mitrasinovic, Med. Chem. 2014, 10, 252-270. DOI:10.2174/157340641003140304143442 
32. P. M. Mitrasinovic, Can. J. Chem. 2003, 81, 542-554. DOI:10.1139/v03-043

33. P. M. Mitrasinovic, Curr. Org. Chem. 2010, 14, 198-211. DOI:10.2174/138527210790069857

34. M. Garcia-Calvo, E. P. Peterson, B. Leiting, R. Rue, D. W. Nicholsoni, N. A. Thornberry, J. Biol. Chem. 1998, 273(49), 32608-32613. DOI:10.1074/jbc.273.49.32608

35. R. Z. Cer, U. Mudunuri, R. Stephens, F. J. Lebeda, Nucl. Acids Res. 2009, 37, W441-W445. DOI:10.1093/nar/gkp253
36. O. Julien, M. Zhuang, A. P. Wiita, A. J. O’Donoghue, G. M. Knudsen, C. S. Craik, J. A. Wells, Proc. Natl. Acad. Sci. U. S. A. 2016, 113(14), E2001-E2010. DOI:10.1073/pnas.1524900113

37. P. J. Henderson, Biochem. J. 1972, 127, 321-333. DOI:10.1042/bj1270321

38. P. J. Munson, D. Rodbard, J. Recept. Res. 1988, 8, 533-546. DOI:10.3109/10799898809049010

39. J. Kudelova, J. Fleischmannova, E. Adamova, E. Matalova, J. Physiol. Pharmacol. 2015, 66(4), 473-482.

\section{Povzetek}

Zaradi različnih bioloških in zdravstvenih razlogov je razvoj humanih zaviralcev kaspaze-2 ključnega pomena. V članku je izpeljan hibridni (kvantno mehanski / molekularno mehanski - QM / MM), dvoplastni molekulski model s ciljem boljšega razumevanja afinitete in specifičnosti interakcije peptidnih zaviralcev s kaspazo-2. Z upoštevanjem edinstvenih strukturnih značilnosti in katalitične aktivnosti človeške kaspaze-2 se kritični aminokislinski preostanki encima (E217, R378, N379, T380 in Y420) s peptidnim zaviralcem obravnavajo na ravni QM (z uporabo t.i. Self-Consistent-Charge Density-Functional Tight-Binding method with the Dispersion correction (SCC-DFTB-D)), preostali del kompleksa pa se obravnava na ravni MM (t.i. AMBER force field). QM/MM vezavne proste energije (VPE) dobro korelirajo $\mathrm{z}$ eksperimentalnimi opazovanji in kažejo, da kaspaza-2 daje prednost penta-peptidu, kot je VDVAD. Zaporedje VDVAD smo sistematično spreminjali tako, da smo upoštevali fizikalno-kemijske lastnosti vsake aminokisline in njenega substituenta, pri čemer smo ovrednotili ustrezne VPE $\mathrm{z}$ inhibicijsko konstanto $\left(\mathrm{K}_{\mathrm{i}}\right)$. Vrednosti $\mathrm{K}_{\mathrm{i}}$ za več kompleksov kaspaza-2:peptidni inhibitor se nahajajo $\mathrm{v}$ eksperimentalnem območju (med 0,01 $\mathrm{nM}$ in $1 \mu \mathrm{M})$. Zaporedje afinitet je: VELAD $\left(\mathrm{K}_{\mathrm{i}}=0,081\right.$ $\mathrm{nM})>\operatorname{VDVAD}\left(\mathrm{K}_{\mathrm{i}}=0,23 \mathrm{nM}\right)>\operatorname{VEIAD}\left(\mathrm{K}_{\mathrm{i}}=0,61 \mathrm{nM}\right)>\operatorname{VEVAD}\left(\mathrm{K}_{\mathrm{i}}=3,7 \mathrm{nM}\right)>\operatorname{VDIAD}\left(\mathrm{K}_{\mathrm{i}}=4,5 \mathrm{nM}\right)$ itd. Navajamo pogoj aproksimacije, ki mu je potrebno zadostiti s kinetičnimi parametri (Michaelisova konstanta $-\mathrm{K}_{\mathrm{M}}$ in konstanta specifičnosti - $\mathrm{k}_{\mathrm{cat}} / \mathrm{K}_{\mathrm{M}}$ ) za kompetitivno inhibicijo. Ocenjene vrednosti $\mathrm{k}_{\mathrm{cat}} / \mathrm{K}_{\mathrm{M}} \mathrm{v}$ eksperimentalno določenem območju (med $10^{-4}$ in $10^{-1} \mu \mathrm{M}^{-1} \mathrm{~s}^{-1}$ ) kažejo, da sta VELAD in VDVAD najbolj specifična za kaspazo-2. Ta dva peptida sta skoraj 1,5, 3 in 4-krat bolj specifična za receptor od peptidov VEIAD, VEVAD in VDIAD. Naveden je tudi dodatni kinetični prag, ki je namenjen razločevanju med tesno vezanimi zaviralci.

Except when otherwise noted, articles in this journal are published under the terms and conditions of the Creative Commons Attribution 4.0 International License 